University of Nebraska - Lincoln

DigitalCommons@University of Nebraska - Lincoln

Faculty Publications, Classics and Religious

Studies Department

June 1990

\title{
THE ALL SOULS DEUTERONOMY AND THE DECALOGUE
}

Sidnie White Crawford

University of Nebraska-Lincoln, scrawford1@unl.edu

Follow this and additional works at: https://digitalcommons.unl.edu/classicsfacpub

Part of the Classics Commons

Crawford, Sidnie White, "THE ALL SOULS DEUTERONOMY AND THE DECALOGUE" (1990). Faculty Publications, Classics and Religious Studies Department. 13.

https://digitalcommons.unl.edu/classicsfacpub/13

This Article is brought to you for free and open access by the Classics and Religious Studies at DigitalCommons@University of Nebraska - Lincoln. It has been accepted for inclusion in Faculty Publications, Classics and Religious Studies Department by an authorized administrator of DigitalCommons@University of Nebraska - Lincoln. 


\title{
THE ALL SOULS DEUTERONOMY AND THE DECALOGUE
}

\author{
SIDNIE ANN WHITE \\ Albright College, Reading, PA 19612
}

4QDtn, the All Souls Deuteronomy, is the best-preserved of all the Deuteronomy manuscripts from Cave 4, Qumran. ${ }^{1}$ A photograph and partial translation of the manuscript were published by Frank Moore Cross in 1969 in the catalogue "Scrolls from the Wilderness of the Dead Sea." The manuscript consists of four complete columns and two partially damaged columns. Columns 2-6 are one continuous sheet of leather, with a sewn edge on col. 2. Column 1 has two sewn edges and was originally attached to the beginning of col. 2 (the columns were separated in the process of restoration). The manuscript was well prepared; the scribe used both horizontal and vertical dry lines, marking the horizontal dry lines with points jalons. ${ }^{3}$ The manuscript is dated, on paleographical grounds, to the early Herodian period (30-1 BCE). The orthography of the manuscript is much fuller than that of either the MT or the Samaritan Pentateuch.4

The contents of col. 1 are Deut 8:5-10. Columns 2-6 contain Deut 5:1-6:1. It is with the portion of the manuscript containing the Decalogue, or Ten Commandments, that this paper will be concerned. The Decalogue, as is well known, exists in two versions: the version found in Exodus (or the Priestly version) and the version found in Deuteronomy (the Deuteronomic version). Although the versions are substantially the same, there are certain differences between the two, particularly in the fourth commandment, and these differences raise the questions of which is the more ancient version, and of the possibility of recovering the original text of the Decalogue from

1 The purchase of this scroll was made possible by All Souls Church (Unitarian), New York City, hence its name.

${ }_{2}$ Frank Moore Cross, Jr., Scrolls from the Wilderness of the Dead Sea (Berkeley, CA: University of California Press, 1969). The complete scroll, with photographs, will be published in DJD 10, forthcoming from Oxford University Press.

${ }^{3}$ A dry line is a line ruled onto the uninscribed leather by a sharp instrument as a guide to the scribe for the placement of his text. Points jalons are dots in ink at the beginning of each line, made by the scribe to aid in the placement of the dry lines.

${ }^{4}$ For a complete discussion of the paleography and orthography of this manuscript, see my "A Critical Edition of Seven Deuteronomy Manuscripts from Cave IV, Qumran: 4QDta, 4QDtc, 4QDtd, 4QDtf, 4QDtg, 4QDti and 4QDtn" (diss., Harvard University, 1988). 
either or both of the two versions. This paper will attempt to locate the All Souls Deuteronomy version of the Decalogue within the history of the transmission of the text and to illuminate some of the text-critical questions concerning the Decalogue. The witness to the Decalogue found in the All Souls Deuteronomy is firmly in the tradition of Deuteronomy 5:6-21, but has been infected by the Priestly tradition (Exod 20:1-17) at one crucial point (see below). In addition, it preserves unique readings at several points.

A transcription of each commandment of the Decalogue as found in the All Souls Deuteronomy follows (line numbers refer to the transcription for ease of location; please refer to the photograph for the actual column and line numbers of the manuscript. Deut 5:1 commences at the beginning of col. 2). The word vacat indicates an empty space in the manuscript. ${ }^{5}$ Following the transcription, I will give textual notes dealing with the Decalogue, collating the important witnesses to Deuteronomy and Exodus against the All Souls witness. I will also collate the evidence of the Nash Papyrus. ${ }^{6}$ The sigla are as follows:

\begin{tabular}{|c|c|}
\hline M & The MT of Deuteronomy according to $B H S$ \\
\hline G & $\begin{array}{l}\text { The critical reconstruction of the Old Greek text where } \\
\text { no significant variants exist }\end{array}$ \\
\hline $\mathrm{G}^{\mathrm{A}}$ & $\begin{array}{l}\text { A F M (y) (z) [the symbol (-) indicates that not all of the } \\
\text { manuscripts in a group agree on the reading] }\end{array}$ \\
\hline $\mathrm{G}^{\mathrm{B}}$ & Vaticanus \\
\hline GC & The catena texts \\
\hline$G^{L}$ & $\mathrm{~d}(\mathbf{n}) \mathrm{pt}^{7}$ \\
\hline $\mathrm{GO}^{\mathrm{O}}$ & The Hexaplaric text \\
\hline $\mathbf{S}$ & The Samaritan Pentateuch \\
\hline Syr. & The Syriac Peshitta \\
\hline $\mathrm{Tg}$. & The text of Targum Onqelos \\
\hline $\mathrm{Vg}$. & The Vulgate \\
\hline
\end{tabular}

5 These empty spaces do not coincide with sětûmôt or pětuhhôt as found in the MT. In fact, they are not meant deliberately to indicate a space in the text, rather, they seem to be the result of avoidance of bad patches on the leather.

6 The Nash Papyrus is a papyrus manuscript, found in Egypt, which W. F. Albright dated to the second half of the second century BCE. It contains the entire Decalogue (mainly following Exodus) and the Shema' on a single leaf. It appears to have been a type of lectionary. For further information and bibliography, see W. F. Albright, "A Biblical Fragment from the Maccabaean Age: The Nash Papyrus," JBL 56 (1937) 145-76. For my text of the Nash papyrus (hereafter PapNash), I am using the anonymous transcription published in $R B 1$ (1904) 142-50.

7 These minuscules are designated by J. Ziegler as the Lucianic text (Joseph Ziegler, "Zur Septuaginta-Vorlage im Deuteronomium," ZAW 72 (1960) 237-62). J. W. Wevers does not believe a Lucianic text can be isolated in Deuteronomy (Text History of the Greek Deuteronomy [Göttingen: Vandenhoeck \& Ruprecht, 1978] 20-30). However, these manuscripts consistently fall together and often contain independent readings. I therefore agree with Ziegler that these minuscules form a major group and feel that, although an Antiochan provenance is by no means assured, it may serve as a convenient label. 


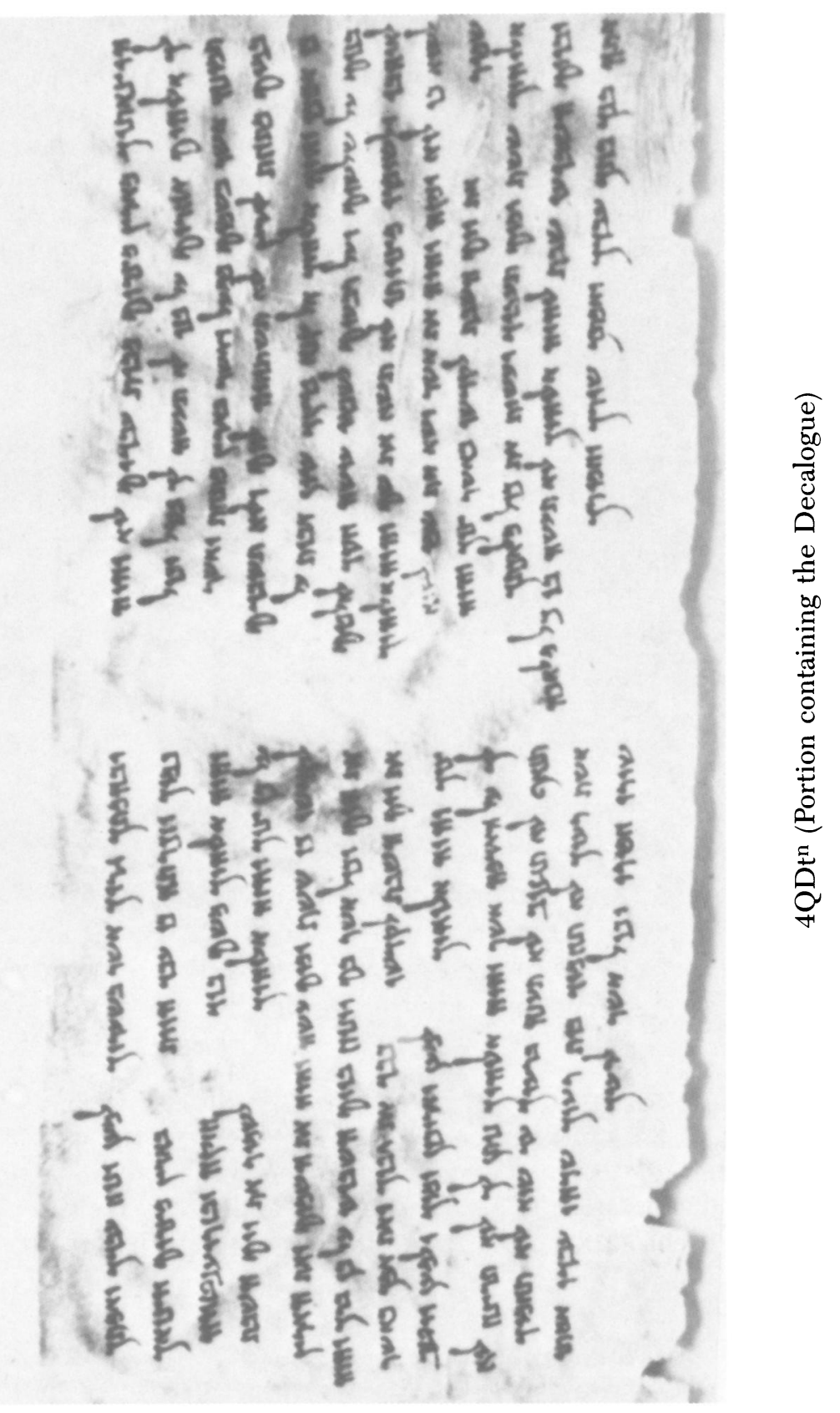




\author{
MEx The MT of Exodus \\ GEx The Old Greek of Exodus \\ SEx The Samaritan text of Exodus
}

This paper is set up in the following manner: the commandment as it appears in the All Souls Deuteronomy is given, along with the chapter and verse of Deuteronomy. The text-critical notes follow; the All-Souls reading is given, then the witnesses which agree with it are collated, followed by a large bracket. ${ }^{8}$ Following this bracket the readings which differ from All Souls are given. (The siglum > indicates that the witness does not contain the $4 \mathrm{Q}$ reading.) Finally, I will discuss the preferable reading. In the case of minor variants, a discussion will be omitted.

\title{
The First Commandment
}

Deut 5:7

\section{לוא יהיה}

לך אלוהים אחרים על פני

Line 1, 5:7 יהיה M, S, PapNash, Syr., Tg., Vg., MEx, SEx] cf. G, GEx,

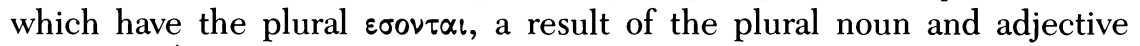
אלהים אחרים.

\section{The Second Commandment}

Deut 5:8-10

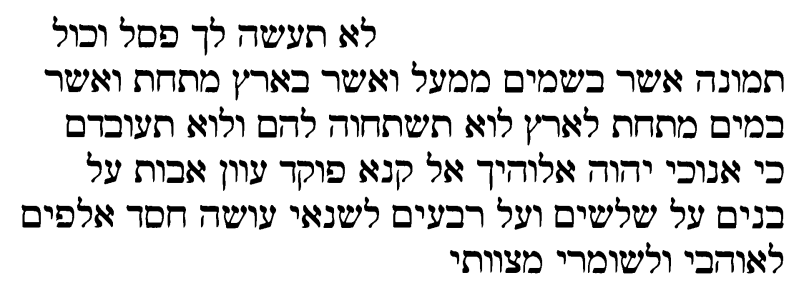

Line 1, וכול G:8, S, Syr., Vg., MEx, GEx, SEx] כל M, Tg.

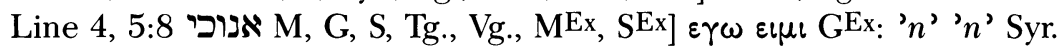
The verb "to be" is not necessary in the Hebrew phrase; it was supplied by the Greek translators. It is a characteristic of the $x \alpha i \gamma \varepsilon$ recension to distinguish between אני מככי by using the verb זוז a with the former and not

${ }^{8}$ It will be noticed that I do not collate the evidence of the phylactery texts found at Qumran. The reason for this omission is that all the phylacteries present "mixed" texts, which are not useful for text-critical purposes. The interested reader is directed to J. T. Milik, "Tefillin, Mezuzot et Targums (4Q128-4Q157)," DJD 6, 33-91. 
with the latter, but I have not found a similar pattern in Deuteronomy9 The Syr. has been infected by GEx at this point.

Line 5, 5:9 על שלשים G, S, PapNash, Syr., Vg., MEx, SEx] ועל שלשים M: cf. Tg.

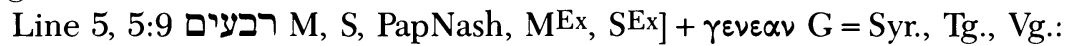
$+\gamma \varepsilon v \varepsilon \alpha \varsigma$ GEx.

Line 5, 5:10 M, G, S, Syr., Tg., Vg., MEx, GEx, SEx.

Line 6, מצוותי G:10 G, S, PapNash, Syr., Tg., Vg., MEx, SEx] מצותו M. Waw and yod are virtually indistinguishable in this script; therefore, the $4 \mathrm{Q}$ reading is materially uncertain. However, M's reading makes no sense in context and seems to be the result of confusion of waw and yod (note also the reading of $\mathrm{M}^{\mathrm{Ex}}$ ); therefore, it seems likely that $4 \mathrm{Q}$ has the preferable text with $\mathrm{G}$ et al.

\section{The Third Commandment}

Deut 5:11

\section{לוא תשא את שם יהוה אלוהיך לשוא כי לוא ינקה יהוה את אשר ישוח ישא את שמו לשוא}

Line 1, 5:11 יהוה (second occurrence) M, G, S, Syr., Tg., Vg., MEx, SEx] xupros o $\theta$ cos бou GEx. The Greek of Exodus is exhibiting assimilation to a common formula, which appears earlier in the verse.

\section{The Fourth Commandment}

Deut 5:12-15

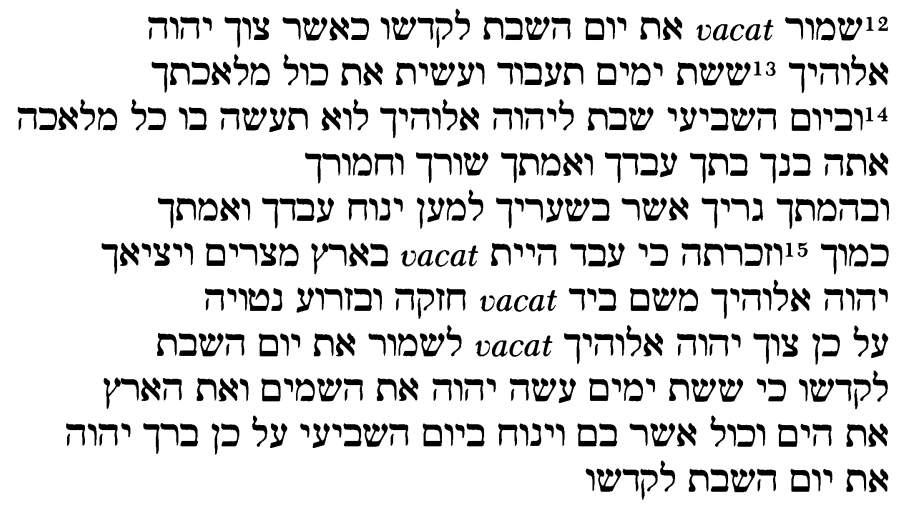

Line 1, 5:12 שמור M, GA-B C L O-, S, Syr., Tg., Vg., SEx] זכור MEx, GA- O-,

${ }^{9}$ S. R. Driver, Notes on the Hebrew Text and the Topography of the Books of Samuel (Oxford: Oxford University Press, 1912) lix. 
$G^{E x}$, PapNash. The different traditions of Deuteronomy and Exodus are clear here. The reading of the Samaritan Exodus is assimilated to the Samaritan text of Deuteronomy, while the reading זכור of the few Greek manuscripts of Deuteronomy is assimilated to the Priestly tradition.

Lines 1 and 2, 5:12 כאשר צוך יהוה אלוהיך M, G, S, Syr., Tg., Vg.] > MEx, $G^{E x}, S^{E x}$, PapNash. Again, this reading gives a clear distinction between the traditions of Deuteronomy and Exodus.

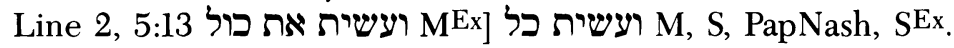

Line 3, 5:14 וביום השביעי M, G, GEx, Syr., Tg., $\mathrm{M}^{\mathrm{Ex}}$, SEx: septimus dies $\mathrm{Vg}$. It is difficult to determine the preferable text; however, it may be argued that the preposition in the tradition of $\mathrm{G}$ is an addition for clarification.

Line 3, 5:14 תעשה בו כל G, S, PapNash, Syr., Vg., GEx] תששה כל M, Tg., MEx, $S^{E x}$. The second reading is perhaps the result of haplography (bet and $k a p h$ are extremely similar in the hand of this period).

Lines 4 and 5, 5:14 The text-critical problem raised here is the original version of this list.

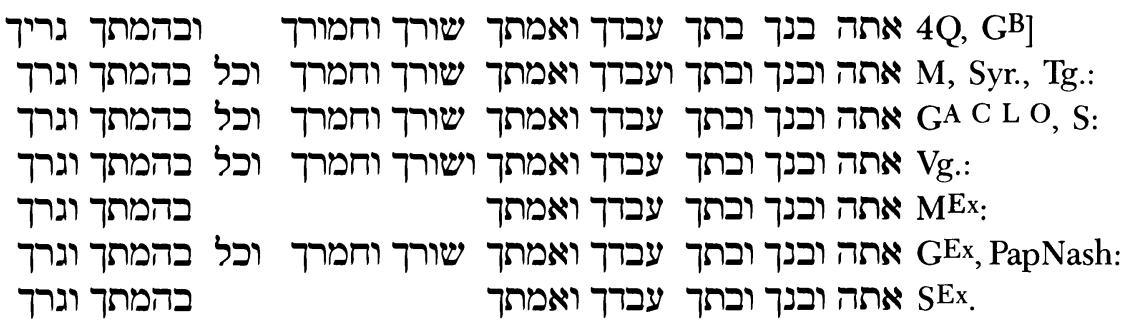

Several observations can be made. First, there is great variation in the presence or absence of the waw conjunctive. Second, the Priestly and Deuteronomic traditions show reciprocal influence. Third, this manuscript is unique for its paucity of the waw conjunctive, while $\mathrm{M}$ shows the greatest use of the waw conjunctive.

It is possible to separate the Priestly and the Deuteronomic traditions. The Deuteronomic tradition consistently contains שורך וחמורך, while Exodus does not in all cases. The presence of שורך וחמורך in GEx and the Nash Papyrus can be explained as the result of the influence of Deuteronomy ${ }^{10}$

Once separate lists have been isolated for the other witnesses to Exodus and Deuteronomy, the preferable versions of those lists must be reconstructed.

${ }^{10}$ It is interesting that the influence of Deuteronomy is found in $G^{E x}$ and the Nash Papyrus together. F. M. Cross has stated that the Vorlage of the Septuagint is an Egyptian local text (The Ancient Library of Qumran and Modern Biblical Studies [rev. ed.; Grand Rapids: Baker, 1961] 181 ), and, of course, the provenance of the Nash Papyrus is Egypt. $G^{\mathbf{E x}}$ and the Nash Papyrus must stem from the same Hebrew Vorlage, at home in Egypt, which was, in this instance, influenced by the version of the Decalogue found in Deuteronomy. 
In order to do this the presence or absence of the waw conjunctive in the various lists must be accounted for. First, each list contains several elements which can be grouped into sets of two: son-daughter, manservant-maidservant, and ox-ass (in the case of Deuteronomy). The clue to grouping these may be found in the phrase ואמתך .עברך ואמתך (with the conjunction) is found in every single version. Making the phrase עברך ואמתך a paradigm, I would phrase our groups of two as follows: שורך וחמורך, עברך ואמתך, עברך וברך. Second, there are several elements in the list which stand alone: You, your beast, your sojourner. Since they stand alone, they should be considered in relation to the groups of two. אתחה must stand alone as the primary addressee, followed by the group specifying the family. The word בהמתך raises two questions: should it be preceded by waw and should it be preceded by כל? It may be argued that in Deuteronomy בהמתך serves as the climax of the "animal" group, and therefore should be joined to that group with וכל. However, in the Priestly version of the list, it immediately follows the

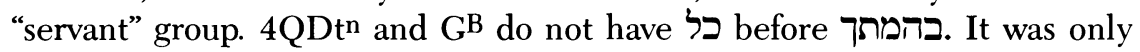
after שורך וחמורך were added in the Deuteronomic version in order to specify to which beasts the list was referring (lists have a tendency to expand), that כל ובהמתך to make it the climax of the "animal" group."11 Finally, גרך stands alone as the final member of the household. I prefer to place a conjunction before it since it ends the list and the conjunction makes a smooth reading. However, its absence in $4 \mathrm{QDt}^{\mathrm{n}}$ may indicate that the conjunction is not original.

Thus, I have reconstructed the more primitive version of Exodus as:

אתה בנך ובתך12 עבדך ואמתך בהמתך וגרך

And the more primitive version of Deuteronomy as:

אתה בנך ובתך עברך ואמתך שורך וחמורך ובהמתך וגרך

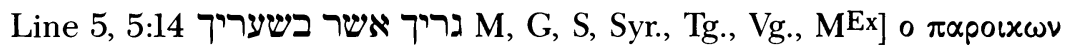
$\varepsilon \nu$ бo $G^{E}, G^{E x}$. The Greek reading appears to be a synonymous variant. ${ }^{13}$

11 This would fall under the rubric of lectio brevior. It might also be argued that the conjunction was added before בהמתך when the animal group was added to the Deuteronomic text, and that the original reading was בהמתך. My personal preference would be for בהמתך without the conjunction, but there is no support in the Deuteronomic witnesses for this reading.

12 Frank Moore Cross has argued against the inclusion of the conjunction before בתך on the grounds that conjunctions are added rather than deleted. This is certainly true (Cross and D. N. Freedman observe that the conjunction is frequently introduced at the beginning of cola where it originally did not belong. See also their appendix, giving a table with the evidence for this practice in 2 Samuel $22=$ Psalm 18 [Cross and Freedman, Studies in Ancient Yahwistic Poetry (SBLDS 21; Missoula, MT: Scholars, 1975) 29]); however, in this case we can argue that the conjunction was omitted in $4 \mathrm{QDt}^{\mathrm{n}}$ by haplography. Given the grouping of pairs in this list, we feel that the conjunction is original.

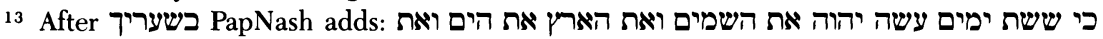
כל אשר בם וינח ביום השביעי על כן ברך יהוה את יום השביעי ויקרשיו. This agrees, for the most 
Lines 5 and 6, 5:14 למען ינוח עבדך ואמתך כמוך M, G, S, Syr., Tg., Vg.] , $M^{E x}, G^{E x}, S^{E x}$, PapNash. This phrase is unique to the Deuteronomic version of the fourth commandment.

Line 5, 5:14 ואמתך M, GA C, S, Syr., Tg., Vg.] GC(-329) 127 adds o ßous oov

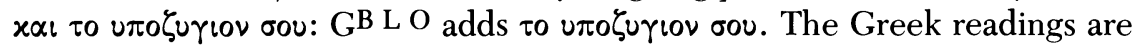
exhibiting conflation from the list in 5:14 above.

Lines 6-7, 5:15

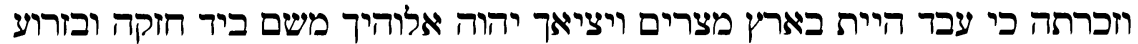

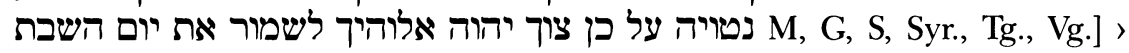
$M^{E x}, G^{E x}, S^{E x}$, PapNash. This is the reason given in Deuteronomy for the sabbath commandment.

Line 8, 5:15 לשמור G, Syr., Tg., Vg.] לעשות M, S. The text of 4Q, G et al. is the result of reminiscence of the first word of 5:12, the beginning of the sabbath commandment. The text of $\mathrm{M}$ and $\mathrm{S}$ is preferable.

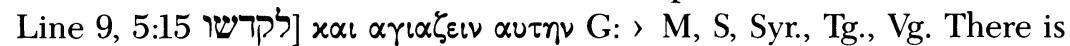
no trigger for the loss of לקדשו in Deuteronomy. G and 4Q have been influenced here by the end of the commandment in Exodus, which reads ויקרשהו (see also below).

Lines 9-11, 5:15 After לקרשו, 4Q adds, against all the Deuteronomic witnesses:

לקרשו כי ששת ימים עשה יהוה את השמים ואת הארץ את הים וכול אשר בם

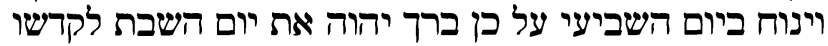

The text of $M^{E x}$ and $S^{E x}$ reads:

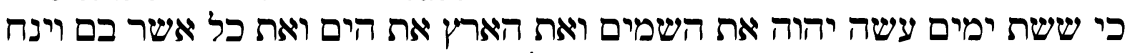

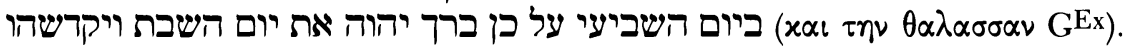

$4 \mathrm{Q}$ has included the reason for the sabbath observance from the Priestly version of the fourth commandment. The Priestly reason is surrounded on either side by לקרשו לקרשו לקו לקו The first in Deuteronomy in G as well as in 4Q. The second לקרשו is echoed by Exodus at the end of the fourth commandment, which reads ויקרשהו. It should be noted, however, that the verb in Exodus is a finite verb, not an infinitive construct. Therefore, there are two infinitive constructs in $4 \mathrm{QDt}^{\mathrm{n}}$ not found elsewhere in the tradition. These infinitive constructs were used as seams (by the scribe of $4 \mathrm{QDt}{ }^{\mathrm{n}}$ or his Vorlage) to surround the addition of the Exodus text. It might be suggested that לקרשו ... לקרשו were triggers for haplography in the early stages of the writing down of the fourth commandment, but if they were, both infinitive constructs have disappeared in most witnesses (the second possibly being

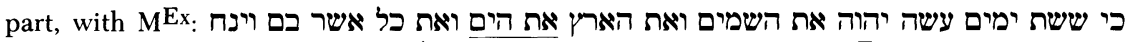

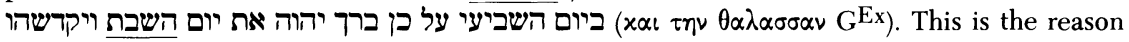
given in the Exodus tradition for the sabbath commandment. The Nash Papyrus has the Exodus version of the Decalogue, which has been infected by Deuteronomy, just as $4 \mathrm{QDt}^{\mathrm{n}}$ is a Deuteronomy manuscript that has been infected by Exodus (pace Albright et al.). 
replaced by a finite verb in Exodus); the first, however, according to the mechanics of haplography, should have remained. It is possible but not very likely that both should have disappeared, leaving only a few witnesses. We know, however, from the Samaritan Pentateuch and other witnesses, that at this period conflation was occurring in the text of the Pentateuch. It was not unusual for the texts of Deuteronomy or Exodus to be expanded with the parallel passages of the other. ${ }^{14}$ This phenomenon is known as harmonization..$^{15}$ As Emanuel Tov states, harmonizations may be intentional or unintentional. Both types seem to be present here; the first, the presence of the first לקרשו, is unintentional harmonization (or reminiscence) of the text with the Decalogue in Exodus. The second, the addition of the Priestly reason for the sabbath commandment in $4 \mathrm{QDt}^{\mathrm{n}}$, appears to be intentional. The evidence of the Nash Papyrus, where the same harmonization occurs but yields a different text, would lead to the same conclusion. It is striking that this type of harmonization of the text of the Decalogue was not more widespread; the two different versions have reached us in largely pristine exemplars.

\section{The Fifth Commandment}

Deut 5:16

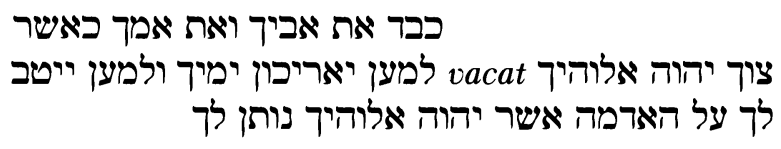

Lines 1 and כאשר צוך יהוה אלוהיך M, G, S, Syr., Tg., Vg.] > MEx, GEx, SEx, PapNash. The phrase is unique to the Deuteronomic version.

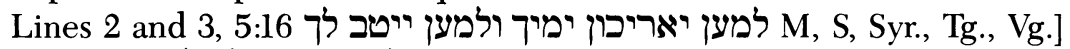

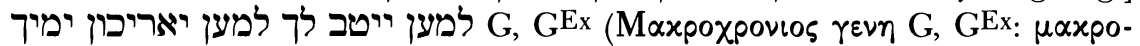

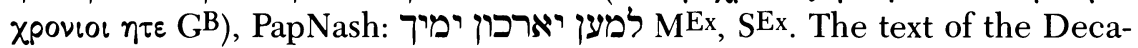
logue has suffered from haplography owing to homoioarchton and subsequent misplacement. $G$ and $G^{E x}$ appear to preserve the preferable text. The text suffered haplography owing to homoioarchton from למען to למען, with the result that the phrase ייטב לך ולמען was lost. The shorter text was retained in the Priestly tradition of M and S. However, in the Deuteronomic tradition of $\mathrm{M}$ and $\mathrm{S}$ the loss of the phrase was recognized and replaced at

14 Cf. Judith E. Sanderson (An Exodus Scroll from Qumran: 4QpaleoExodm and the Samaritan Tradition [HSS 30; Atlanta: Scholars Press, 1986] 207), who points out "three major interpolations" in 4QpaleoEx ${ }^{m}$ from Deuteronomy which that manuscript shares with the Samaritan Pentateuch. Mr. Nathan Jastram of Harvard University has also informed me that the same phenomenon occurs in 4 QNumb.

15 For a good discussion of harmonization, see Emanuel Tov, "The Nature and Background of Harmonization in Biblical Manuscripts," JSOT 3 (1985) 3-29. 
the end of ימיר. 4Q shares the error of this reading.16

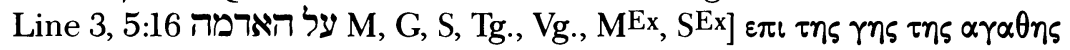
$\mathrm{G}^{\mathrm{Ex}}: b^{\prime} r^{\prime}$ ' $t b t^{\prime}$ Syr. The reading of GEx and the Syr. is an expansion.

\section{The Sixth, Seventh, and Eighth Commandments}

Deut 5:17-19

\section{לוא תרצח לוא}

\section{תנאף לוא תגנוב}

Lines 1 and 2, 5:17-19 These verses raise the question of the order of the sixth, seventh, and eighth commandments, that is, prohibitions of murder, adultery, and stealing. There are at least three orders from the Decalogue itself:

\section{לא תרצח לא תנאף חרצ לאר

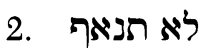 לא תרצח לאנח \\ 3. לא תנאף לאבר

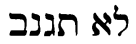 לא תגנב לא תגנב לא תרצח}

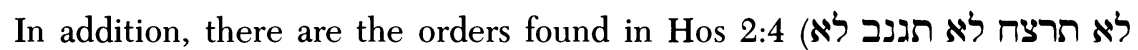
(תנאף) and Jer 7:9 (לא תגנב לא תרצח לא תנאר).

The first order may be termed the "Old Palestinian" order, since all the manuscripts which make up the "Old Palestinian" group are represented, that is, GA C O, S, SEx, as well as $M, M^{E x}$, and its daughter versions, Syr., Syr.Ex, Tg. and Vg.17 4QDt" exhibits the "Old Palestinian" order. In fact, all the phylacteries so far published from Qumran which contain the Deuteronomic Decalogue use the "Old Palestinian" order (i.e., 4QPhylb, 4QPhylg, and 4QPhylj). In addition, Josephus (Ant. 3.5.5); Matt 5:21, 27; 19:18; and Mark 10:19 all exhibit the "Old Palestinian" order.

The second order may be termed the Egyptian order, since Vaticanus and the Nash Papyrus (both Egyptian texts) preserve it. Also, GC L(Ex) (not Egyptian texts) have this order. In the NT, Luke 18:20; Rom 13:9; and Jas 2:11 exhibit the Egyptian order. In addition Philo preserves this order, as might

16 It is also possible that למען יאריכון ימיך was original to the Exodus tradition, למען ייטב לך to Deuteronomy, and that most of the witnesses are conflate. However, we have no evidence for the shorter reading in Deuteronomy. Therefore, we have given the explanation above as the more likely cause of the corruption.

17 Cross discusses the "Old Palestinian" group in some detail: "By 'Old Palestinian' we mean the text type current in Palestine at the end of the fifth century B.C. (sic)" (Ancient Library, 189 n. 41). Emanuel Tov has disagreed with the use of the term "text type" ("A Modern Textual Outlook Based on the Qumran Scrolls," HUCA 53 [1982] 19). He is correct to advocate caution. However, it appears that we can at least talk about groups of texts; that is, texts that exhibit agreement in error and other peculiarities against other texts. In Deuteronomy, the complete witnesses to the text of Deuteronomy are MT, LXX, and S; therefore, these witnesses serve as a norm by which to arrange groups of texts, although they do not necessarily contain the bestpreserved text within the group. 
be expected from his Egyptian provenance. The third order is unique to the Old Greek of Exodus.

It seems clear that the "Old Palestinian" order was original to the text of Deuteronomy, since Vaticanus alone in Deuteronomy is not considered a reliable witness. ${ }^{18}$ It is also likely that the Egyptian order is original to Exodus, since there is strong Greek evidence for it outside of Egypt (as well as the Nash Papyrus). The order of $\mathbf{M}$ and $\mathrm{S}$ and the daughter versions in Exodus may be explained as the result of the influence of Deuteronomy. Therefore, I have two orders, one reflected in the original text of Exodus, the other in the original text of Deuteronomy. Beyond this, however, text criticism will not take us. The original order of the sixth, seventh, and eighth commandments in the most ancient version of the Decalogue is not clear.

Lines 1 and 2, 5:17, 18, 19 לוא MEx, G, GEx, S, SEx, Syr., PapNash (where extant)] ולא M, Tg., Vg. The waw conjunctive is not original to the negative commandments.

\section{The Ninth Commandment}

Deut 5:20

\section{לוא תענה ברעיך ער שוא}

Line 1, 5:20 לוא MEx, G, GEx, S, SEx, Syr., PapNash] ולא M, Tg., Vg. The waw conjunctive is not original to the negative commandments.

Line 1, 5:20 שוא MEx, SEx. Gyr., Tg., PapNash] שקר MEx GEx have $\phi \varepsilon v \delta \eta$, which could translate either שקר שת or. The tradition of Deuteronomy is united behind שואה. The Priestly tradition is divided, with M and S using שקר, and the Egyptian group (I am assuming that $G^{E x}$ and PapNash agree, as usual) using שוא . שוא appears to be original in Deuteronomy, while שקר may be original in Exodus. These appear to be ancient variants.

\section{The Tenth Commandment}

Deut 5:21

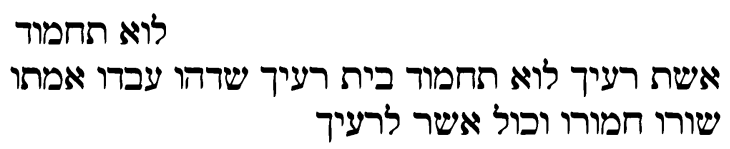

Lines 1 and 2, 5:21 Again, the question is of the original version of the list: 


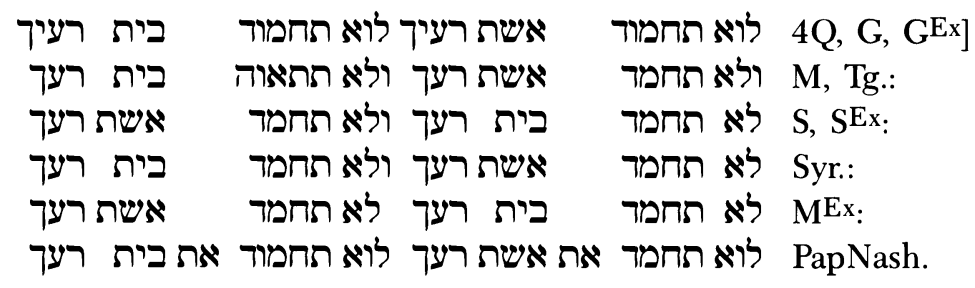

Several variants present themselves. Two can be easily resolved: the presence of the direct object marker in the Nash Papyrus and the addition of conjunctions before $\boldsymbol{W}$ in the various traditions. These are prose particles which crept into the text and can be eliminated. ${ }^{19}$ The first major variant among the traditions is the second verb. The MT of Deuteronomy (and its targums) has תתאוה, while all the other witnesses have תחמר. I would restore the more difficult verb תמואה as the preferable reading, viewing the second תחמר as leveling through from the first verb. ${ }^{20}$

The second major variant involves the word order. The Priestly and Deuteronomic traditions are thoroughly confused at this point. Text criticism is not helpful, except to show that there is a tendency to level through the order "wife ... house" (all our later witnesses preserve this order). G. E. Wright (among others) has suggested that the order of Exodus is earlier, and that in this context means "household," with the list that follows specifying that which belongs to the household. Later, when the wife gained an improved status, the list in Deuteronomy reflected this improved position. ${ }^{21}$ William Moran, however, uses the Ugaritic legal contracts with their lists of possessions to prove that the list in Deuteronomy can be every bit as ancient as that of Exodus and implies no special status for women. Ugaritic lists are usually headed by the word for house $(b \bar{\imath} t \bar{u})$, which can mean "house," "house and land," or "land." It often appears in the formulaic expression bìtū $\bar{u} e q l \bar{u}$, "house and field." When it appears in this expression the word order is fixed. The other formulaic expression that appears in these Ugaritic lists is the phrase "everything belonging to him," which concludes the list in every case. Thus, the typical scheme of the Ugaritic legal documents is "house and field" + specifications + generic closing formula. The order of the parts is rigid. This is precisely the order of the list in Deuteronomy after the second verb (see below). Typologically, then, the list of Deuteronomy is very old. As Moran states, "If this is a typical list of common possessions subject to sale,

19 Cross and Freedman note that the direct object marker appears very infrequently in ancient texts (Ancient Yahwistic Poetry, 28).

20 As William Moran points out, the verbs are practically synonymous, so it cannot be supposed that one represents any "refinement of moral standards" over the other ("The Conclusion of the Decalogue," CBQ 29 [1967] 543, 545).

${ }^{21}$ G. Ernest Wright, Deuteronomy (IB 2; New York: Abingdon-Cokesbury, 1953) 368. 
exchange, or inheritance, then the wife has no place in it."22 The wife is placed before the list, in a completely separate position. This does not imply a movement beyond Exodus, where the wife is considered a part of the household. Rather, it is simply a matter of using a different, though equally ancient, formula. Therefore, there are two ancient variants, and one cannot be assigned priority over the other ${ }^{23}$

Lines 2 and 3, 5:21 The problems here are very similar to those in 5:14.

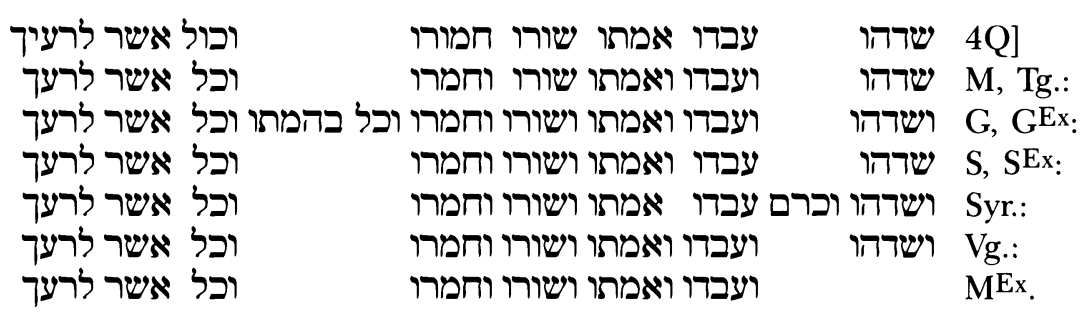

There are almost as many lists as witnesses. In two of the lists, a certain amount of expansion has taken place. The list of $G$ and $G^{E x}$ has expanded because of the influence of the list in 5:14 (the addition of שרה בהמתו and כרם appear together many times in the Hebrew Bible, including Exod 22:4; 1 Sam 22:7; Jer 32:15; and Neh 5:3, 4, 5. This explains the Syriac expansion. Neither of these expansions is to be taken as pointing to the original text. The reconstruction of the original list may be approached as was the list in 5:14, by placing together the groups of two שורו וחמרו and It ואדו ואמתו. It may be argued that the groups without the conjunction, witnessed by $4 \mathrm{Q}$, are preferable. However, it may also be argued that these waws dropped out of $4 \mathrm{Q}$ by reason of haplography (since the preceding words end in waw). At the end of the list, all the other witnesses agree on וכל אשר לרעך, which serves as the climax to the list. This leaves the problem of שרהו. If it is original, it should stand alone, and should not have the waw conjunction (as in $4 \mathrm{Q}, \mathrm{M}$, S, SEx, Tg.). However, MEx does not contain שרהו. This raises the question of its originality. The list in 5:14 above does not contain שרהו, and the tradition of $M^{\mathrm{Ex}}$ may have deleted it under that influence. ${ }^{24}$ Therefore, I reconstruct this list as:

\section{שרהו עבדו ואמתו שורו וחמרו וכל אשר לרעך}

\footnotetext{
${ }_{22}$ Moran, "The Conclusion of the Decalogue," 548-52. Moran gives as an example the list of RS 16.148 +, which is a royal grant to a certain Takhulenu. The list reads "his houses, his fields, his menservants, his maidservants, his oxen, his asses, everything else belonging to him."

${ }^{23}$ Moran, in fact, does suggest that in the original list of commandments, Deut 5:21a and 5:21b were two separate commandments ("The Conclusion of the Decalogue," 554 ). If this is so, then Deuteronomy would be earlier than Exodus, Exodus stemming from a period when the two separate commandments were put together, with "household" at the head of the list.

24 Also, see the arguments of Moran cited above concerning the Ugaritic formulaic pair $b \bar{t} t \bar{u}$ $\bar{u}$ eqlü.
} 
It is clear from the above discussion that the witness to the Decalogue found in the All Souls Deuteronomy does stand clearly in the tradition of Deuteronomy. At 5:12, All Souls contains שמור, the verb of the Deuteroכאשר צוך יהוה 5omic tradition. All Souls uses, at 5:12 and 5:16, the phrase אלהיך, which appears only in the Decalogue of Deuteronomy. The phrase שורך וחמורך (5:14), in the household list, appears chiefly in the Deuteronomic tradition, infecting the Old Greek of Exodus and the Nash Papyrus. At 5:20, Deuteronomy contains שואר instead of a reading which 4QDt ${ }^{n}$ shares. Finally, at 5:21, the All Souls shares with the other witnesses to Deuteronomy the word order בית, Sששת. So much, then, is clear. Can it be placed within a group of witnesses in the Deuteronomic tradition? There are only two cases of shared error in the All Souls' witness, at 5:16 (commandment 5) and 5:21 (commandment 10). At 5:16, 4Q agrees in error with $M, S$, and the daughter versions of $\mathbf{M}$; at 5:21, with $G$ and $G^{E x}$. There is not enough evidence here to draw a sound conclusion. When discussing the order of the sixth, seventh, and eighth commandments, I noted that the All Souls was a witness to the "Old Palestinian" order (as opposed to the Egyptian order), as were all the published texts from Qumran. This, again, does not allow us to draw any conclusion, except to say that there was a tendency at Qumran to level through the "Old Palestinian" order.

The most striking thing about this manuscript is the conflation evident in the fourth commandment. Clearly, in this period the distinction between the Decalogues in Exodus and Deuteronomy had become somewhat blurred (witness also the earlier Nash Papyrus). However, this conflation certainly did not occur in all witnesses, at Qumran or elsewhere.25 So once again, there is not enough evidence on which to base a judgment. What finally must be said is that the All Souls Deuteronomy bears witness to a text of the Deuteronomic Decalogue, which is, with one important exception, almost free from error and very close to what may be presumed to be the original text of the Deuteronomic Decalogue.

25 E.g., 4QPhyla, 4QPhyl ${ }^{\mathrm{b}}$. 